\title{
THE USE OF FINANCIAL MANAGEMENT PRACTICE BY BATIK PEKALONGAN MSMES
}

\author{
Moch. Lutfi \\ lutfimoch.1403@gmail.com \\ Ellen Rusliati \\ Universitas Pasundan \\ J1. Tamansari No. 6-8, Bandung 40116
}

diterima: 20/12/2019; direvisi: 26/7/2020; disetujui: 27/8/2020

\begin{abstract}
Micro, Small, and Medium Enterprises (MSMEs) are recognized worldwide as the main source of dynamism, innovation, and flexibility. This study aims to analyze the financial management practices used by the Pekalongan batik craft SMEs. The method used is descriptive with a qualitative approach. Data were collected by structured interviews with a samples are 30 determind by snowwball sampling. The results show that the owner's knowledge of financial management is still limited, did not prepared a financial budget regularly, and rarely compare the budget with the actual results. Most owners had check supplies once a week and did not evaluate the feasibility before started to invest. Range for ROA were $2 \%$ to $5 \%$, and NPM $10 \%$ to $20 \%$. All owners are satisfied with doing the business, and no one to thinks of moving to other businesses in other fields.
\end{abstract}

Keywords: SMEs; financial management; financial performance; company value; qualitative descriptive

\section{INTRODUCTION}

MSMEs are recognized worldwide as the main source of dynamism, innovation, and flexibility. They are responsible for making most job opportunities, contributing for both productivity and economic growth. They are the start-up of logical mechanism for creating job opportunities and public's future wealth in a nation and also play important role in most countries' economic. Therefore, the government all around the world would focus more on the development of MSMEs sector to support economic growth (Fatoki, 2012).

The success or failure of MSMEs depend on the continuation of their financial condition. It also lays on one of their skills to secure their cash flow and sufficient capital in order to gain more profit (Frimpong, 2014). Today, most MSMEs only focus more on targeting the sales and market and ignore the main position of their financial management. In the business management pattern, the role of company's financial management and risk's control have not been running optimally, which, in this case, will cause negative effect on the credit and financing the MSMEs in China. This is because of the lack of model of effective financial management (Wang, 2019).

Financial management, or also called company's finance, focuses on the decision which is related to how many and what type of assets that will be obtained is, how to to increase the capital needed buy the assets and how to run the company to maximize its value (Brigham \& Houston, 2019). There are six financial management practices, namely: financial planning and control, financial analysis, accounting information, management accounting, investment appraisal and capital management. This study focuses on the financial planning and control, capital management and investment appraisal (Fatoki, 2012). The practice of financial management, such as accounts receivable management, inventory management, cash management and asset management are important and also give effects to the performance of MSMEs (Nketsiah, 2018). In this study, I focus on 3 main variables, namely: the financial planning, working capital management and investment appraisal.

The company believes that financial planning would help achieve its long-term purposes. Its performance could be increased by planning the precise financial calculation. The entrepreneur and financing staff should have known general knowledge and understaning about the cost-income and input-output planning. The skill of planning the enterprises, expansion, forecasting and risk analysis are beyond their ability to apply the decision-making process (Akhmedov, 2017).

The failure of financial structure and fund allocation might be the cause of financial distress in a company (Sunarji \& Sufyani, 2017). The period of cash conversion, the date of accounts receivable and the date of inventory 
turnover are significantly and negatively related to the performance itself. On the other hand, the turnover of accounts receivable is positively related to the performance, which means that the effective working capital has effect on the performance of SM Enterprise. The implication of this result is seen by reducing the period of cash conversion, time of accounts receivable collection and date of inventory turnover, therefore the SM Enterprise could improve their profitability (Lamptey et al., 2017). The MSMEs need incentives and specific program to make them obtained the credit access with appropriate tax, either to improve management practice or labor capacity (Lopes de Sousa Jabbour et al., 2020).

The failure and reduced investment in the MSMEs sector are mostly related to characteristic of informality in business operation. It means that the MSMEs are known for its disobedient on either business practice or best investment. Financial operation and management are poorly regulated and operators are also barely adhering to best practices (Ndanyenbah, 2019). Investment decision is one of the parts of financial management functions in a company. Financial management should allocate the fund in a form of profitable investment in the future (Anggia \& Suteja, 2019). This study aims to find out (1) financial management practice, (2) planning and financial control, (3) capital management, (4) financial performance and (5) company value on MSMEs of Batik Pekalongan handcraft.

\section{METHOD}

This study uses descriptive qualitative method, by carrying out direct observation, structured and direct interview. The population of this study consists of 663 enterpreneurs who fit the predetermined criteria. I used snowball sampling, which finally led to an interview for as much as $30 \mathrm{MSMEs}$ available. Activity of collecting qualitative data was interactively and continuously carried out, until the data became saturated. Activity of model analysis consisted of data collection, data reduction and verification.

\section{RESULT}

The use of financial management practice in the MSMEs of Batik Pekalongan handcraft is still using traditional way (Table 1). All owners themselves of the enterprises are responsible for financial issues inside and do not take advantage of accountant services. This is for minimizing the cost. Half of the respondents manage the financial issues by their ownselves based on what they know (Table 2). Therefore, the education level becomes one of the factors showing the fact that it is hard to run and manage the use of financial practice inside the enterprise. Almost all owners have never attended any financial training. There are only 1 respondent who have attended it, even though he/ she did not really get what has been conveyed in the training. This showed that the financial management was not optimally used.

Table 1. Biography Information

\begin{tabular}{lc}
\hline Biography Question & Frequency \\
\hline Business Status & 25 \\
Individual & 5 \\
Cooperation & \\
Age & 0 \\
$21-30$ & 6 \\
$31-40$ & 18 \\
$41-50$ & 6 \\
$51-60$ & \\
Level of Education & 1 \\
SD (Primary) & 6 \\
SMP (Junior) & 10 \\
SMA (High) & 3 \\
D3 (Diploma) & 10 \\
Sarjana (Bachelor) & \\
Gender & 23 \\
Man & 7 \\
Woman & \\
Total employee & 16 \\
$<10$ people & 11 \\
People & 3 \\
$>21$ people & \\
Age of the Company & 6 \\
$<10$ & 15 \\
11-20 & \\
$>20$ &
\end{tabular}

Table 2. Financial Management

\begin{tabular}{lcc}
\hline Question on Financial Management & Frequency & $(\%)$ \\
\hline Person-in-charge on Financial Issues & & \\
Owner & 30 & 100 \\
Accounting Staff & 0 & 0 \\
Financial Management Training Attendance & & \\
$\quad$ Yes & 1 & 3,33 \\
No & 29 & 96,67 \\
Financial Report Ownership & & \\
$\quad$ Yes & 0 & 0 \\
Traditional & 25 & 83,33 \\
No & 5 & 16,67 \\
The Importance of Financial Management & & \\
Yes & 30 & 100 \\
No & 0 & 0 \\
\hline
\end{tabular}

All owners of MSMEs of Batik Pekalongan handcraft considered the importance of financial management without even knowing the reasons. Based on their lack of knowledge, the financial management practices they have been running are still considered traditional. The respondent only focus on maintaining simple and short-term financial issues, such as production cost and payment roll which is budgeted once every week and did not use the practice of long-term financial management, such as evaluating the investment feasibility. 
Most of the MSMEs of Batik Pekalongan only has their own financial report to be reviewed by their own enterprise (without the accounting standard), even most respondents confirmed that they did not have any report to be reviewed more than 3 months. The accounting standard which can be implemented in the MSMEs, also called as SAK ETAP (Standar Akuntansi Keuangan untuk Entitas Tanpa Akuntabilitias Publik) has also not been well implemented.

Most of the owners of MSMEs lack in understanding the financial planning and management. They assume that it is important to run and manage the financial issues the same time they work, but also they only make it for one week ahead and compare it to the previous week. Business activities end once a week: on Thursday (every Friday is off). On Thursday all financial activities will be closed, from the distribution of salaries to the calculation of income.

All owners confirmed that the planning on financial issues is important (Table 3), but they are not well organized in preparing financial budget. The owner of the enterprise itself made a financial budget of $48 \%$ which was lower than in the study (Brijlal, 2014), of about $59 \%$. This showed that the respondent rarely prepares a financial budget and lacks of understanding the function of it. The costs which has been spent also often do not match the budget that has been prepared before. It made some respondents feel that managing the financial budget was not really important in running their business. They admitted that they only spent cash when they needed it to: including purchasing raw materials and paying salaries, without carrying out a careful financial budget planning. Some respondents only remembered the production costs when buying equipment without proper recording.

Table 3. Financial Planning

\begin{tabular}{ll}
\hline No & \multicolumn{1}{c}{ Questions } \\
\hline 1. How important is the financial planning? \\
2. How orderly is preparing financial budget? \\
3. How far is the owner involved in preparing financial budget? \\
4. To what extent does the owner interpret and use the financial \\
budget? \\
5. How important is the financial budget in giving useful \\
information for the need of decision-making? \\
6. How often does the ownver compare the financial budget \\
7. How ofter is the financial technique implemented in financial \\
8. How computerized is the financial report practice in a \\
business?
\end{tabular}

All owners of the enterprises were involved in preparing the financial budget, but they lacked of financial analysis and use. This was described in Table 3 (No. 4) stating about the extent to which the owner interpreted and used the financial budget, with a score of $38 \%$. The owner of the enterprise did not take decision based on the budget, but based on personal opinion. This is described in column 5 stating about how important it is the financial budget in providing useful information for decision making purposes with $43 \%$.

Most of the owners of the enterprises also did not compare their financial budget with the real result. It is described in No. 6 stating about how often it is to compare financial budget to the real results with a score of $44 \%$. This score is still lesser than what has been carried by (Brijlal, 2014) who showed the score of $63 \%$ from similar case. The owner has not implemented the financial technique in analyzing the financial issues which was described in No. 7 stating about how often the financial technique was implemented in analyzing financial issues in a business, with a score of $38 \%$. Meanwhile, the previous research carried out by (Brijlal, 2014) scored 64\%. It was because of the lack of respondent's knowledge about financial management, namely also because of their level of education that is mostly below High School and the absence of respondentsw who have attended financial management training.

There were no enterprises which used computerized system to maintain their financial report practice in their business. A computerized system actually can make every financial record a lot much easier: namelyl from maintaining financial budget and company's financial report. Other than that, it is much easier for a company in saving the recorded data if they use the system, including viewing the long-term financial budget and financial report, as long as there is damage in the computer or the data is not erased.

The importance of a record actually can make it easier for the owner in analyzing the condition of financial fluctuation report for every period, including in making decision. Cost becomes the critical factor. In order to save cost, the owner decided not to buy expensive computer equipment. Besides, the owner's lack of skill in running computer system is also the reason for the owner not to use a computerized system. The age factor (above 30 years old) also makes them lazy to learn it all. Actually the benefits of important computer equipment can cover these costs. However, the decision remains in the hands of the owners of MSM Enterprises of Batik Pekalongan.

Almost all owners, about $97 \%$ of MSMEs of Batik Pekalongan of respondents did not save their money in the bank (Table 4). It was lower than in the previous research carried out by (Fatoki, 2012) showing that about $57 \%$ of total respondents had saved their money in the bank everyday. This allows the bank to develop a deposit history and facilitate the availability of credit for MSMEs. 
Table 4. Working Capital Management

\begin{tabular}{|c|c|c|c|c|}
\hline No & \multicolumn{2}{|l|}{ Question } & Yes & No \\
\hline 1. & \multicolumn{2}{|c|}{$\begin{array}{l}\text { Do the owners keep their money } \\
\text { in the bank every day? }\end{array}$} & 1 & 29 \\
\hline 2. & \multicolumn{2}{|c|}{$\begin{array}{l}\text { Do the owners sell product in } \\
\text { credit? }\end{array}$} & 7 & 23 \\
\hline 3. & \multicolumn{2}{|c|}{$\begin{array}{l}\text { Do the owners record the due-date } \\
\text { payment to the creditor? }\end{array}$} & 7 & 23 \\
\hline 4. & \multicolumn{2}{|c|}{$\begin{array}{l}\text { Do the owners purchase the } \\
\text { supplies in credit? }\end{array}$} & 8 & 22 \\
\hline 5. & \multicolumn{2}{|c|}{$\begin{array}{l}\text { Do the owners record your due- } \\
\text { date payment? }\end{array}$} & 8 & 22 \\
\hline 6. & $\begin{array}{l}\text { How often do the } \\
\text { owners check on the } \\
\text { supplies? }\end{array}$ & $\begin{array}{l}\text { Per Day } \\
\quad 2\end{array}$ & $\begin{array}{l}\text { Per Week } \\
28\end{array}$ & $\begin{array}{c}\text { Per Month } \\
0\end{array}$ \\
\hline 7. & $\begin{array}{l}\text { How do the owners } \\
\text { decide to purchase the } \\
\text { supplies? }\end{array}$ & $\begin{array}{l}\text { When out } \\
\text { of stock } \\
16\end{array}$ & Periodically & $\begin{array}{c}\text { Depend } \\
\text { on orders } \\
8\end{array}$ \\
\hline
\end{tabular}

There were only some respondents, about $23 \%$, who sold their products on credit and recorded the due-date from the creditor. It indeed creates the high risk of unpaid accounts. However, if a company wanted to expand its market, it need to take the risk to sell the products. Compared to previous research by (Fatoki, 2012), he stated that about $67 \%$ of respondents sold the product on credit and some of them recorde the due-date for creditor to pay the debt.

Some MSMEs of Batik, about $27 \%$, bought their supplies on credit and recorded the due-date for paying the debt. As comparison to the previous research, (Fatoki, 2012) stated that about $39 \%$ bought the supplies on credit and some of them recorded the due-date for paying. It allowed the owner to spend the money for other necessities, for example to divert the fund used for paying cash to invest a long-term investment to support the business.

Almost all MSMEs of Batik checked on their material supplies every week while the rest of them had done it everyday. It was carried out because the enterprise should have finished the financial report once every week. As a comparison to the previous research, (Fatoko, 2012) stated that about 2\% of the owners had checked on their supplies every day, $63 \%$ of them every week, $32 \%$ of them every month while the rest of them had never checked on them.

Most of MSMEs of Batik, for about $53 \%$, decided to buy raw material supplies periodically, $27 \%$ of them when there is an order, while the rest of them when they are out of stock. By purchasing the supplies when there is an order, it could reduce the risk of build-up supplies. In the other hand, it could also narrow its potential market. There were only some institutions or companies who order the supplies and when the have financial issues or go bankrupt, the MSMEs that rely only on orders will be greatly affected. As comparison to the previous research (Fatoki, 2012)stated that about 35 out of 57 respondents decided to purchase the supplies when it was out of stock, the rest of 22 decided to purchase the supplies periodically.

Almost all Batik MSMEs of respondents did not evaluate the feasibility before starting to invest. As comparison, the research carried out by (Fatoki, 2012) stated that about $98 \%$ of respondents had not evaluated the investment feasibility before starting to invest. Those who evaluated the business feasibility used payback method. Evaluation of investment feasibility is needed to carry out the long-term decision-making. For example, when purchasing machine equipment, the owner could know the effectivity and the exact time of investment capital will return.

Almost all of Batik MSMEs, about $93 \%$ spent their own capital and decided not to use loan capital and that they are not willing to take risks for repayment of it. The use of loan capital could actually make and develop the business even larger. There were only $6.67 \%$ who used loan capital, by the ratio of $20 / 80$ and $30 / 70$ with their own capital.

Most of Batik Pekalongan MSMEs respondents experienced a profit decline in the last month, as a result of the raw material price increase. This caused the owner to reduce his profit in order to maintain their product price. Other than than, the Java-cross highway is one of the factors which caused the decline of visitors in Batik Pekalongan market. Batik handcraft has been very fluctuative; it could be profitable, but it could also be otherwise. Its turnover may vary; 10 million per week or even up to 100 million per week. The weak economic condition force the Batik MSMEs to be more patient. There are only $3 \%$ of them which gained profit in the last month, while $20 \%$ of them admitted that the profit they have gained tend to be more stable.

The comparison between profit gained by Batik MSMEs and its total asset was about $2 \%$ to $5 \%$ every week. By this comparison, I could calculate the ROA (Return on Asset). This score was considered reasonable for manufacturing companies, quite small, and if seen from these results, this is due to the equipment that are not cheap to make Batik. It could possibly be different with the other trading company which only sell Batik without carrying the production process. We could see from the score that the ROA was $2 \%$. Therefore, it should need a turnover approximately 50 times profit to return the initial capital.

The comparison between profit gained by MSMEs Batik Enterprises and its nett sales was about $10 \%$ to $20 \%$. By this comparison, I could measure the NPM (Net Profit Margin). This score was considered as a standard of NPM. The owner usually takes the profit as much as $20 \%$ of the total production cost when selling the product in retail. However, if there are owners who sell in wholesales (in large quantities), the owner only gains profit as much as $10 \%$ to $15 \%$ of the total production cost. 
Most of the owners of Batik MSMEs run the business from generation to generation. All the reason is because their environment forced them to. Business require a lot of capital, artistic spirit of their mind as well as the ability and knowledge of textiles and chemical preparations used in the Batik production process. This is usually obtained from the legacy of either previous owner of the MSMEs or their environment.

All owners of Batik MSMEs felt satisfied in running their business and no one thought of running or moving to other business. This was done to: (1) keep the preservation of ancestral culture, (2) keep the business which has been supporting the family from generation to generation, (3) keep the business which has been large asset. The business is a legacy whose market is only controlled by certain circles and not everyone can easily handle it. It is hard for other businessman/woman who want to go to Batik market.

There were no people thinking to move to other business, but there were some who thought to expand their business larger, for example, running the retail business of daily necessitie (sembako). This was done to widen the livehood when the economy grown weakened and Batik market fails to get customers. Therefore, the owner can still keep the earnings from the businesses themselves.

All owners of Batik MSMEs admitted that carrying out financial planning is really important, but they also lack of preparing the financial budget (Table 3 ). This is described in Question No. 2, which scored 48\%, lower than in the previous research carried out by (Brijlal, 2014) stating that the score was $59 \%$. It also showed that the respondent barely prepared the financial budget, meanwhile most of the respondents spent the cash only when they needed to: including for purchasing raw materials and paying for employee's salaries, without analyzing proper financial budget planning. Most of the respondents only remembered the production cost when they purchased them without proper record.

All owners of Batik MSMEs were involved in preparing financial budget, but they also lack of analyzing and using them. It was described in Question No. 4, which scored 38\%. The owner of Batik MSMEs did not make decision based on the budget, but based on their personal opinion, which was described on Question No. 5 scored of $43 \%$.

Most of the owners of Batik MSMEs also did not compare the budget to its real result. This was described on the Question No. 6, which scored 44\%. It was lower than in the previous research by (Brijlal, 2014) showing the score of $63 \%$ of the similar case. The owner did not implement financial technique in analyzing their financial issues, described in Question No. 7, with a score of $38 \%$ while (Brijlal, 2014) scored of $64 \%$. This was because their lack of knowledge about financial management, as well as their education background as explained before and lack of training.
There were no Batik MSMEs which used a computerized system for running the financial report in their business. A computerized system could make every record in a business a lot easier, namely from managing financial budget and report as well as keeping the data for a long-term period (as long as the data has not been erased or damaged).

The importance of a record could actually allow the owner to analyze financial fluctuation periodically to make a decision. Cost savings are the reason why owners did not buy computers. In addition, inadequate computer skills are also the reason the owner did not use a computerized system. Also, the age which is above 30 years old made them unwilling to learn about it.

Table 5 showed us that most of Batik MSMEs $(66 \%)$ rarely set the financial purposes to be achieved in the next one year. This was proved by the Question No. 1, which showed better score from the previous research by (Fatoki, 2012) stating that about $96 \%$ of the respondents did not set the short-term financial purposes. Implementing the short-term financial purpose could actually become the base for the owner to make decision, including deciding the amount of products which should be produced.

Table 5. Discussion on Practice of Financial Planning and Management

\begin{tabular}{ll}
\hline No & \multicolumn{1}{c}{ Questions } \\
\hline 1. & Is the financial goal to be achieved within 1 year set? \\
2. & Is the financial goal to be achieved within 5-10 years set? \\
3. & Do you compare your financial goal to your financial \\
& performance? \\
4. Is trading trend analyzed? \\
5. Is cost trend analyzed? \\
6. Is profit trend analyzed?
\end{tabular}

Most of the owners of Batik MSMEs, about 78\%, also did not set the long-term purpose. This score was better than in the previous research carried out by (Fatoki, 2012) stating that $100 \%$ of respondents have not set the long-term purpose. The implementation of long-term financial purpose is useful for the company to estimate their needs in the future. When the owners only depend on the suppliers to fulfil the production needs, the companies are forced to follow supplier regulation. This could be avoided when the long-term planning had only been carried out. The owners could purchase their own weaving machine to expand the company if needed.

The owner of Batik MSMEs who compared their financial purposes to the real result was about $36 \%$. This was better than in the previous research carried out by (Fatoki, 2012) which was only $2 \%$. If the financial purpose is not reviewed and compared to the actual result, it means that the financial management was 
inoptimally carried out and the evaluation of financial performance cannot be carried out as well.

Most of the owner of Batik MSMEs, about $68 \%$ also did not analyze the trading trend. This score was better than in the previous research carried out by (Fatoki, 2012) who showed up 91\%. Trend analysis is actually useful a lot more effective and efficient for arranging the amount of product which should be produced.

There were $34 \%$ of the owner of Batik MSMEs who analyzed cost trends which can be the basis for making decision in further expenses. Profit trend analysis was carried out by about $33 \%$ of the owners. By analyzing it, the owner could possibly know the direction of fluctuating profit growth.

The result of research carried out by (Fatoki, 2012) stated that there were $90 \%$ of respondents that did not set the short-term purpose and no respondent that set the long-term purpose. In addition, Fatoki also stated that $98 \%$ of respondents did not compare the purpose to its performance and $91 \%$ of respondents did not carry out financial analysis to determine trading trend, cost and profit. The research result by (Brijlal, 2014) stated that $80 \%$ of the owners found that financial planning is very important, $59 \%$ of them have already prepared a financial budget, $69 \%$ of them were involved in the budget preparation process and implemented it, while $59 \%$ of them set the financial planning techniques learned in the training and $64 \%$ use computerized financial reporting techniques. A research carried out by (Akhmedov, 2017) which was Likert-scale based showed that the attitude towards financial planning was positive, because its effect on company policy problems is treated relatively less favorable.

\section{DISCUSSION}

(Van Horne, James C; Wachowicz, John M., 2012) stated that there were two main concepts of working capital, namely net and gross. Generally, accountants refer to net working capital which represents the difference in the value of money between current assets and short-term liabilities. Meanwhile, financial analysts refer to the concepts of gross working capital.

(Fahmi, 2015) stated that working capital is a company's investment on short-term assets, such as cash, securities, inventory and accounts receivable. (Fatoki, 2012) stated that $57 \%$ of total respondents did not keep the money in the bank every day, $67 \%$ of them sold the product in credit, while the rest of 39\% purchased the supplies in credit. A research result carried out by (Asad Ullah et al., 2019) stated that there was positive relation of bank cost usage for working capital and sales growth, as well as all source of formal fund used to invest still had positive relation with sales growth.

Almost all owners of Batik MSMEs, about 97\%, did not keep their money in the bank every day. This is higher than in the previous research carried out by
(Fatoki, 2012) who showed up the result of 57\%. It also allows the bank to improve deposit history and be able to facilitate credit availability for MSMEs.

There were $23 \%$ of respondents that sold the products in credit and recorded the due-date from the creditor. This makes the risk of bad debts low. However, to create a bigger market, a company should dare enough to take the risk to sell its products. (Fatoki, 2012) stated that there were 38 out of 57 respondents who sold the product in credit and 23 of them recorded the due-date for creditor to pay the debts. About 27\% of respondents of Batik MSMEs purchase the supplies in credit and recorded the due-date for paying. As comparison, (Fatoki, 2012) stated that there were 87\% respondents purchase their supplies in credit and $86 \%$ of them recorded the due-date for paying. It allowed the owner to use their money for other necessities which could also expand their business. By purchasing the product in credit, it allowed the owner to spend the money for other necessities, such as to divert the fund used for paying cash to invest a long-term investment to support the business.

The survey result showed that $93 \%$ of MSMEs had always checked their supplies every week and the rest of them checked the supplies every day. It was done because the MSMEs should have finished their financial issues once in a week. As comparison to the previous research, (Fatoki, 2012) stated that among $57 \%$ of respondents, $2 \%$ of them checked the supplies every day, $63 \%$ every week, $32 \%$ every month and the rest 3\% never checked on them.

Most of Batik MSMEs, about $53 \%$, decided to purchase raw materials supplies periodically, $27 \%$ when there were orders and $20 \%$ of them when they are out of stock. By purchasing the supplies when there is an order, it could reduce the risk of build-up supplies but it could also narrow its potential market. The research result by (Fatoki, 2012) showed that $62 \%$ of respondents decided to purchase their supplies when they were out of stock, while the rest of them purchase them periodically.

(Malinda, 2011) stated that investment is a form of postponement of consumption in the present to obtain future consumption, which contains an element of risk of uncertainty. Therefore, that compensation is needed for the delay. In addition, (Tandelili, 2010) stated that investment is a commitment to a number of other funds carried out at the present time, with the aim of obtaining profits in the future.

(Meilicher, Ronald W. and Norton, 2016) stated that economic investment, industry characteristic of a company and competitive effect on the company were reflected in the financial report and how the analyst would check on them. Company strategy and either its success or failure, as well as its strength or weakness, would be clearly seen in the financial report analysis. This information will help the company make the investment decision. 
(Ndanyenbah, 2019) stated that the MSMEs have a significant knowledge on Investment Appraisal Techniques (IATs). The enterprise operator also set the IATs to assess their investment and factors influencing the choice of IATs to assess their investment, which finally turned out to be the gender.

Based on the survey result, about $97 \%$ of Batik MSMEs did not evaluate the investment feasibility before (Table 6). As comparisoan, (Fatoki, 2012) stated that about $98 \%$ of respondents did not evaluate it either. The respondents who evaluated business feasibility used payback method.

Table 6. Investment Appraisal

\begin{tabular}{clcc}
\hline No & Questions & Yes & No \\
\hline 1. & $\begin{array}{l}\text { Do the owners carry out the } \\
\text { investment feasibility evaluation } \\
\text { before starting to invest? }\end{array}$ & 1 & 29 \\
2. & Do the owners use the loan capital? & 2 & 28 \\
\hline
\end{tabular}

Evaluation of investment feasibility is needed to make a long-term decision, such as in purchasing the machine and equipment. The owner could also find out its effectivity and the exact time of investment capital will return.

Almost all Batik MSMEs, about 93.3\% used their own capital and decided not to use loan capital and that they are not willing to take risks for repayment of it. The use of loan capital could actually make and develop the business even larger. Respondents who used loan capital had the ratio of loan capital to own capital, as much as 20/80 and 30/70.

Most of Batik Pekalongan MSMEs, about 77\% had a decline of profit in the last month, as an effect of the increase of raw material price. This caused the owner to think about reducing profits in order to maintain the stability of the price of the product. Other than than, the Java-cross highway is one of the factors which caused the decline of visitors in Batik Pekalongan market. Batik handcraft has been very fluctuative; it could be profitable, but it could also be otherwise. Its turnover may vary; 10 million per week or even up to 100 million per week. The weak economic condition force Batik MSMEs to be more patient. There are only one of them which gained profit in the last month, while the rest of them admitted that the profit they have gained tend to be more stable.

The comparison between profit and its total asset was about $2 \%$ to $5 \%$ every week. For a manufacturing company, this score was considered quite low. It was because of the expensive equipment required to make Batik. The comparison between profit gained by MSMEs Batik and its nett sales was about $10 \%$ to $20 \%$. By this findings, I could measure the NPM (Net Profit Margin). This score was considered as a standard of NPM. The owner usually takes the profit as much as $20 \%$ of the total production cost when selling the product in retail. However, if there are owners who sell in wholesales (in large quantities), the owner only gains profit as much as $10 \%$ to $15 \%$ of the total production cost.

The main purpose of a company is to increase its value by improving the wealth of the owner or shareholders. (Fahmi, 2015) stated that the ratio of company value is a ratio which describes the existing condition in the market. It is able to give understanding for the company's management about the condition that will be carried on and its effect for the future.

(Wahlen, James M; Baginski, Stephen P. and Bradshaw, 2018) stated that the financial analysis has used the estimation of stock value in order to make recommendation for people to purchase, sell, or hold securities, equities from various companies whose market prices are too low, too high, or almost precise. (Harmono, 2011) stated that company value can be measured through stock price in the market based on the formation of the company's share price in the market which was actually also an assessment reflection by public on the company's performance.

The shareholders of Batik MSMEs are mostly the owners themselves. Therefore, I measure the company's value based on the owner's satisfaction in running their business. Based on the survey carried out in March 2129th, 2020, most owners have been running the business from generation to generation. It was also because of their environment, capital, artistic spirit of their mind, skill and knowledge about textiles, as well as chemical preparations used in the production process of Batik.

The entire owners of Batik MSMEs felt satisfied in running their business and none of them would think of running or moving to other business. It was because of various factors, namely to keep the preservation of culture, keep the business which has been supporting the family from generation to generation as well as to keep the business which has been large asset for people in Pekalongan.

There were no people thingking to move to other business, but there were some who thought to expand their business larger, for example, running the retail business of daily necessities (sembako). This was done to widen the livehood when the economy grows weakened and Batik market fails to get customers. Therefore, the owner can still keep the earnings from the businesses themselves.

\section{CONCLUSION}

The conclusions obtained from the results of this study are: (1) The use of financial management practice in Batik Pekalongan MSMEs has been inoptimally implemented and considered simple; (2) The financial planning and management in Batik Pekalongan MSMEs have not been orderly implemented yet; (3) The working capital management in Batik Pekalongan MSMEs 
has been inoptimally implemented; (4) The financial performance in Batik Pekalongan MSMEs tended to decline in the last months, while the company's value tended to be better and more stable.

\section{REFERENCES}

Akhmedov, K. 2017. Financial Planning and Corporate Development: Attitude Analysis of Selected Enterprises in Uzbekistan. International Journal of Management Science and Business Administration, $3(6), 38-42$. https://doi.org/10.18775/ ijmsba.1849-5664-5419.2014.36.1005

Anggia, G., \& Suteja, J. 2019. Keputusan investasi, pendanaan, kebijakan dividen terhadap kinerja keuangan dan nilai perusahaan. Jurnal Riset Bisnis Dan Manajemen, 12(2), 90-98.

Asad Ullah, Khushnood, M., \& Hafizullah. 2019. Working Capital and Fixed Investment Effect on Sales Growth in SAARC Countries' SMEs. Global Social Sciences Review, IV(I), 129-136. https:// doi.org/10.31703/gssr.2019(iv-i).17

Brigham, E. F., \& Houston, J. F. 2019. Fundamentals of Financial Management 15 Edition. Cengage Learning.

Brijlal, P. 2014. The use of financial management practices by small, medium and micro enterprises: a perspective from South Africa. Industry \& Higher Education, 28(5), 341-350.

Fahmi, I. 2015. Pengantar Manajemen Keuangan: Teori dan Soal Jawab. Alfabeta.

Fatoki, O. 2012. An Investigation into the Financial Management Practices of New Micro-enterprises in South Africa. Journal of Social Sciences, 33(2), 179-188. https://doi.org/10.1080/09718923.2012 .11893097

Frimpong, S. 2014. Effect of Demand-Side Factors on Access To External Finance By Micro, Small and Medium Manufacturing Enterprises in Kumasi Metropolis, a Thesis Submitted To School of Business in Partial Fulfilment of the Requirements for the Award of Degree of Doctor O (Issue June).

Harmono. 2011. Manajemen Keuangan Berbasis
Balanced Scorecard. Pendekatan Teori, Kasus, dan Riset Bisnis (1 st ed.). Bumi Aksara.

Lamptey, L., Frimpong, K., \& Morrison, A. 2017. Empirical Study on the Influence of Working Capital Management on Performance of SMEs in a Developing Economy. British Journal of Economics, Management \& Trade, 17(4), 1-10. https://doi.org/10.9734/bjemt/2017/33579

Lopes de Sousa Jabbour, A. B., Ndubisi, N. O., \& Roman Pais Seles, B. M. 2020. Sustainable development in Asian manufacturing SMEs: Progress and directions. International Journal of Production Economics, 225, 107567. https://doi.org/https:// doi.org/10.1016/j.ijpe.2019.107567

Malinda, M. dan. 2011. Pengantar Pasar Modal. (Pertama).

Meilicher, Ronald W. and Norton, E.A. 2016. Intoduction to Finance: Markets, Investments, and Financial Management (16th ed.). Wiley Student Choice.

Ndanyenbah, T. Y. 2019. Application of Investment Appraisal Techniques by Small and Medium Enterprises (SMEs) Operators in the Tamale Metropolis, Ghana. Journal of Economics and Sustainable Development, 10(9), 6-43. https:// doi.org/10.7176/JESD

Nketsiah, I. 2018. Financial management practices and performance of SMEs in Ghana: The moderating role of firm age. Open Journal of Economics and Commerce, 1(4), 8-18.

Sunarji, A., \& Sufyani, M. 2017. Rasio Keuangan Dalam Memprediksi Kondisi Financial Distress Perusahaan Tekstil Dan Garmen. Jurnal Riset Bisnis Dan Manajemen, 10(2), 11. https://doi. org/10.23969/jrbm.v10i2.445

Van Horne, James C; Wachowicz, John M., J. alih bahasa Q. M. 2012. Prinsip-prinsip Manajemen Keuangan (13. Buku I). Salemba Empat.

Wahlen, J. M., Baginski, S. P. and Bradshaw, M. 2018. Financial Reporting, Financial Statement Analysis and Valuation (9th ed.). Cengage Learning Inc.

Wang, H. 2019. Research on Financial Management of SMEs. Icebfm, 142-145. https://doi.org/10.25236/ icebfm.2019.030 